\title{
Disulfide Reduction Converts the Insulin Receptor of Human Placenta to a Low Affinity Form
}

\author{
Steven Jacobs and Pedro Cuatrecasas, Department of Molecular Biology, \\ Wellcome Research Laboratories, Research Triangle Park, North Carolina 27709
}

\begin{abstract}
A B S T R A C T Treatment of human placenta membranes with dithiothietol (DTT) followed by $N$-ethylmaleimide results in a $60 \%$ reduction in insulin binding. Treatment with $\mathrm{N}$-ethylmaleimide alone has little effect. The decrease in insulin binding that results from DTT treatment is due to a decrease in affinity for insulin, with little change in total receptor number. DTT has similar effects on receptor solubilized from placenta membranes with Triton X-100, indicating that its effects are not attributable to changes in the arrangement of receptors in the membrane. In contrast to placenta membranes, treatment of liver membranes with DTT does not decrease insulin binding. These results suggest that reduction of a critical disulfide bond in insulin receptors from human placenta converts the receptor to a low affinity form.
\end{abstract}

\section{INTRODUCTION}

Insulin receptors are composed of multiple subunits linked by interchain disulfide bonds (1-4). In rat liver, the receptor appears to exist in two redox states $(3,4)$. The oxidized form can be converted into the reduced form by the disulfide reducing agent dithiothreitol (DTT). ${ }^{1}$ Similar forms of the receptor exist in human placenta (unpublished observations). In the present work we have determined the effect of treating the receptor with DTT on the subsequent binding of insulin.

\section{METHODS}

Human placenta membranes (5) and rat liver membranes (6) were prepared as described previously, with the modification that $10 \mu \mathrm{g} / \mathrm{ml}$ phenyl methyl sulfonyl fluoride and $5 \mathrm{mM}$ EDTA were included in the homogenization buffer to prevent proteolysis. Placenta membranes $(10 \mathrm{mg}$ protein $/ \mathrm{ml}$ of $50 \mathrm{mM}$ Tris $\mathrm{HCl}, \mathrm{pH} 7.7$ ) were solubilized with $2 \%$ Triton X-100, and after centrifugation at $200,000 \mathrm{~g}$ for $1 \mathrm{~h}$, the supernate was

Received for publication 16 June 1980 and in revised form 17 September 1980.

${ }^{1}$ Abbreviations used in this paper: DTT, dithiothreitol; NEM, $N$-ethylmaleimide. used for studies on solubilized insulin receptors. ${ }^{125}$ I-Insulin was prepared with chloramine-T (7).

Insulin binding to membranes was measured by filtration with EGWP Millipore filters (Millipore Corp., Bedford, Mass.) (8). Insulin binding to the solubilized receptor was measured by the polyethylene glycol assay (9). In all binding studies, the amount of ${ }^{125} \mathrm{I}$-insulin bound in the presence of $20 \mu \mathrm{g} / \mathrm{ml}$ of native insulin was determined and used to calculate the nonspecific binding.

To assess the degree of insulin degradation during the binding studies, the membranes were pelleted by centrifugation at $80,000 \mathrm{~g}$ for $3 \mathrm{~min}$, and the fraction of radioactivity in the supernate that was precipitated by $5 \%$ TCA with $1 \%$ albumin as a carrier was determined.

\section{RESULTS}

The effect of DTT on insulin binding to placenta membranes is shown in Table I. If placenta membranes are incubated with DTT and then with $N$-ethylmaleimide (NEM), which rapidly alkylates accessible sulfhydryl groups, there is a reduction in specific insulin binding. NEM alone causes a considerably smaller, but still significant decrease in insulin binding. Since DTT will rapidly inactivate insulin, it is important that the DTT be fully quenched by NEM before the addition of the ${ }^{125}$ I-insulin. That the DTT is indeed completely quenched by this procedure is shown by reversing the order of addition of the membranes to the incubation. If DTT is incubated with NEM before the addition of placenta membranes, there is no reduction in insulin binding (Table I). Since membrane preparations contain insulin-degrading enzymes, which are sensitive to sulfhydryl reagents (10), it is also important to determine whether the observed decrease in binding is the result of enhanced insulin degradation. As shown in Table $I$, at least $92 \%$ of the ${ }^{125} \mathrm{I}$ insulin was trichloroacetic acid precipitable at the end of the incubation with each of the treatments.

Fig. 1 shows a concentration-effect curve for DTT. Under the conditions used, $0.5 \mathrm{mM}$ DTT produces nearly half-maximal inhibition of binding.

As shown in Fig. 2, a Scatchard plot of insulin binding to placenta membranes that have not been treated with 
TABLE I

Effect of DTT and NEM on Insulin Binding to Placenta Membranes

\begin{tabular}{lcc}
\hline \multicolumn{1}{c}{ Treatment } & $\begin{array}{c}\text { Bound } \\
\text { specifically }\end{array}$ & $\begin{array}{c}\text { TCA } \\
\text { precipitable }\end{array}$ \\
\hline & $c p m$ & $\%$ \\
None & $496 \pm 22$ & $91 \pm 1$ \\
DTT then NEM & $213 \pm 21$ & $91 \pm 1$ \\
NEM & $429 \pm 25$ & $92 \pm 1$ \\
DTT previously alkylated by NEM & $505 \pm 15$ & - \\
\hline
\end{tabular}

Placenta membranes were incubated at room temperature in Krebs-Ringer bicarbonate buffer, $\mathrm{pH} 7.4$, and $0.1 \%$ albumin with no additions; $10 \mathrm{mM}$ DTT for $10 \mathrm{~min}$ followed by 25 $\mathrm{mM}$ NEM for $10 \mathrm{~min}$; no additions for $10 \mathrm{~min}$ followed by $25 \mathrm{mM}$ NEM for $10 \mathrm{~min}$; or $10 \mathrm{mM}$ DTT that had been alkylated with $25 \mathrm{mM} \mathrm{NEM}$ before the addition of membranes. ${ }^{125}$ I-Insulin $(9,500 \mathrm{cpm})$ was then added to each tube and the incubation was continued for $90 \mathrm{~min}$ at $15^{\circ} \mathrm{C}$. The amount of ${ }^{125} \mathrm{I}$-insulin that was specifically bound and that which was trichloroacetic acid (TCA) precipitable was then determined.

DTT is concave. After treatment with DTT, the Scatchard plot approaches linearity, and the initial high affinity portion of the curve is lost with little, if any, change in the total receptor number.

To determine whether inhibition of insulin binding by DTT is a direct effect on the insulin receptor, or whether it results from changes in the plasma membrane or the arrangement of insulin receptors in the plasma membrane, the effect of DTT on insulin recep-

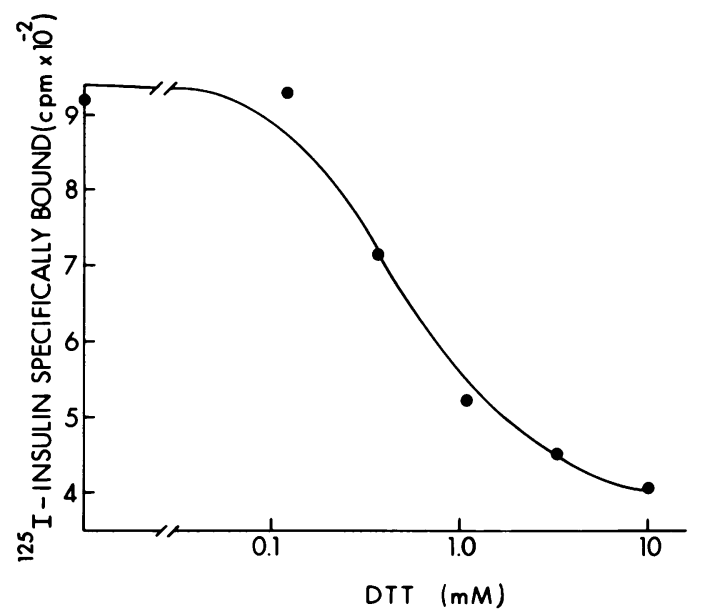

FIGURE 1 The effect of different concentrations of DTT on insulin binding to placenta membranes. Placenta membranes were incubated with the indicated concentrations of DTT at $22^{\circ} \mathrm{C}$ for $10 \mathrm{~min}$. NEM was added to each tube to bring the concentration to $25 \mathrm{mM}$. The specific binding of ${ }^{125} \mathrm{I}$ insulin $(12,000 \mathrm{cpm})$ was then measured after a $90-\mathrm{min}$ period of incubation at $15^{\circ} \mathrm{C}$. tors solubilized from placenta membranes was determined (Table II). Both DTT and NEM decreased insulin binding to solubilized receptors in a manner similar to that observed with membrane-bound receptors.

In contrast to the results with placenta membranes, insulin binding to rat liver membranes in not inhibited by DTT (Table III), but in this tissue, DTT causes a slight enhancement of binding. NEM results in a small inhibition of insulin binding, comparable to that seen with placenta membranes.

\section{DISCUSSION}

These studies demonstrate that treatment with DTT followed by NEM of insulin receptors from placenta membranes diminishes the affinity for insulin binding, presumably by reducing (and alkylating) disulfide bonds. Despite the similarities in the structure and binding properties of insulin receptors from rat liver and human placenta, DTT does not inhibit insulin binding to rat liver membranes.

It has been reported previously (11) that DTT inhibits insulin binding in solubilized human placenta. However, this was attributed to increased insulin degradation, which was also observed after treatment with DTT. In the present study, insulin degradation was minimal and was not significantly affected by DTT.

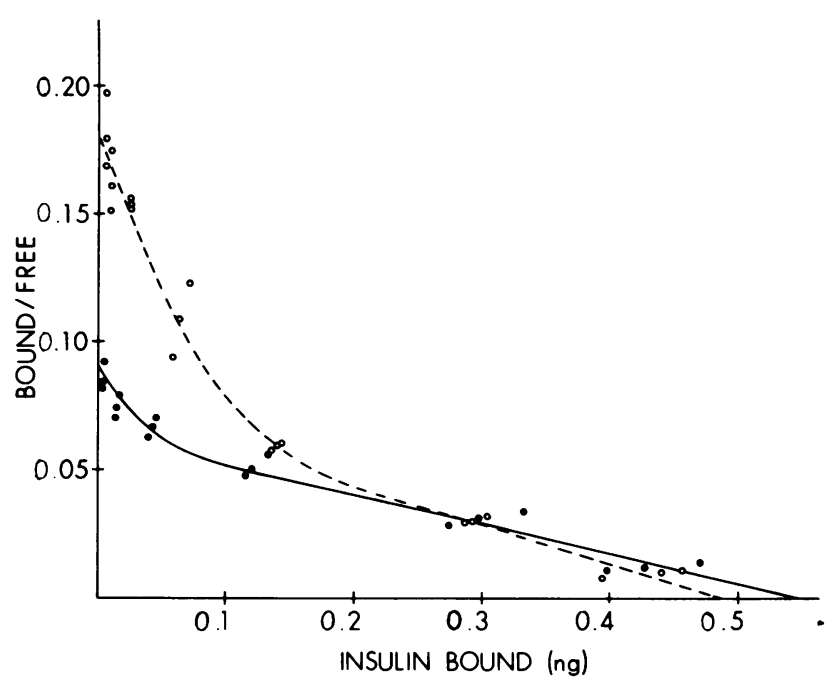

FIgURE 2 Scatchard plots of insulin binding to placenta membranes treated with DTT. Placenta membranes were incubated with or without $5 \mathrm{mM}$ DTT for $10 \mathrm{~min}$ at $22^{\circ} \mathrm{C}$, and then with $12.5 \mathrm{mM} \mathrm{NEM}$ for an additional $10 \mathrm{~min}$ at $22^{\circ} \mathrm{C}$. The specific binding of various concentrations of ${ }^{125} \mathrm{I}$-insulin to 40 $\mu \mathrm{g}$ of DTT-treated (-) membranes or to membranes not treated with DTT (O) after a $90-\mathrm{min}$ incubation in $0.2 \mathrm{ml}$ of Krebs-Ringer bicarbonate buffer, and $0.1 \%$ albumin at $15^{\circ} \mathrm{C}$ was then determined. The ordinate is the ratio of counts per minute bound to counts per minute free. The data are the result of a single representative experiment. 
TABLE II

Effect of DTT and NEM on Insulin Binding to Solubilized Placenta Membranes

\begin{tabular}{lc}
\hline \multicolumn{1}{c}{ Treatment } & Bound specifically \\
\hline & $c p m$ \\
None & $970 \pm 25$ \\
DTT followed by NEM & $390 \pm 16$ \\
NEM & $770 \pm 38$ \\
\hline
\end{tabular}

Solubilized placenta membranes were incubated with no additions, $10 \mathrm{mM}$ DTT followed by $25 \mathrm{mM} \mathrm{NEM}$, or $25 \mathrm{mM}$ NEM as described in the legend to Table I. ${ }^{125}$ I-Insulin $(12,500 \mathrm{cpm})$ was then added to each tube and the incubation continued for $90 \mathrm{~min}$ at $15^{\circ} \mathrm{C}$. The amount of ${ }^{125}$ I-insulin bound was then determined.

These different results are probably best explained by the fact that in the present study, insulin binding was performed at $15^{\circ}$ rather than $37^{\circ} \mathrm{C}$, and DTT was quenched by NEM before the addition of insulin.

Previous reports have described that sulhydryl reagents such as NEM and iodoacetamide have no effect on insulin binding to fat cells (12), liver membranes (13), or placenta membranes (11). We observe a small decrease in insulin binding, but only at considerably higher concentrations of NEM than were used in the previous studies. When we use concentrations of NEM $<10 \mathrm{mM}$, we also observe no significant effect on insulin binding (data not shown).

In a recent paper, the effect of DTT on insulin binding to fat cell membranes was studied (14). As in the present study, DTT tended to linearize the Scatchard plots of insulin binding, and to decrease the affinity of the high affinity sites. However, the affinity of the low affinity sites was increased after treatment with low concentrations ( $1 \mathrm{mM}$ ) of DTT, resulting in a net increase in insulin binding. At high concentrations of DTT, insulin binding decreased below control levels. No such biphasic effects were seen in the present study using placenta or liver membranes. However, we do see similar effects with fat cell membranes (data not shown).

Recent studies have yielded considerable information about the structure of the insulin receptor. It appears to be a tetramer composed of two copies of a subunit having an apparent molecular weight on sodium dodecyl sulfate (SDS)-polyacrylamide gels of about 135,000, and two copies of a lower molecular mass subunit, which may be either 90,000 daltons or 45,000 daltons $(1,3,4,15-17)$. In liver membranes, the receptor exists in different redox states $(3,4)$. In the oxidized state, the four subunits are linked by interchain disulfide bonds, so that the tetramer remains intact after it is denatured by boiling in SDS (1-4). In the reduced state, the native molecule is also a tetramer;
TABLE III

Effect of DTT and NEM on Binding of ${ }^{125}$ I-Insulin to Liver Membranes

\begin{tabular}{lc}
\hline \multicolumn{1}{c}{ Treatment } & Bound specifically \\
\hline & $c p m$ \\
None & $950 \pm 94$ \\
DTT followed by NEM & $1182 \pm 63$ \\
NEM & $770 \pm 30$ \\
\hline
\end{tabular}

Liver membranes were incubated with no additions, DTT followed by NEM, or NEM as described in the legend to Table I. ${ }^{125}$ I-Insulin $(9,600 \mathrm{cpm})$ was added to each tube and after a 90 -min period of incubation at $15^{\circ} \mathrm{C}$ the amount of ${ }^{125}$ I-insulin specifically bound was determined.

however, when it is denatured, it dissociates into dimers composed of one 135,000-dalton subunit and one of the lower mass subunit (1-4).

In view of the results presented in this manuscript, it is tempting to speculate that these different redox forms of the receptor have different affinities for insulin. This could account for the heterogeneous forms of the receptor that have been described previously on the basis of insulin binding (18). Interconversion of redox forms could also account for the rapid changes in the affinity of insulin receptors that occur under various physiological conditions (i.e., fasting, administration of glucose, after binding insulin). However, it is difficult to explain why the effects of DTT are different in rat liver and human placenta, when these two receptors appear to be structurally similar (1).

\section{ACKNOWLEDGMENT}

We thank Stella Cook for excellent technical assistance.

\section{REFERENCES}

1. Jacobs, S., E. Hazum, Y. Shechter, and P. Cuatrecasas. 1979. Insulin receptor: covalent labeling and identificacation of subunits. Proc. Natl. Acad. Sci. U.S.A. 76: 4918-4921.

2. Pilch, P. F., and M. P. Czech. 1980. The subunit structure of the high affinity insulin receptor. J. Biol. Chem. 255: 1722-1731

3. Jacobs, S., E. Hazum, and P. Cuatrecasas. 1980. The subunit structure of rat liver insulin receptor: antibodies directed against the insulin binding subunit. J. Biol. Chem. 255: 6937-6940.

4. Massagué, J., and M. P. Czech. Multiple redox forms of the insulin receptor in native liver membranes. In press.

5. O'Keefe, E., M. D. Hollenberg, and P. Cuatrecasas. 1974. Epidermal growth factor: characteristics of specific binding in membranes from liver, placenta, and other target tissues. Arch. Biochem. Biophys. 164: 518-526.

6. Cuatrecasas, P., and I. Parikh. 1974. Insulin receptors. Methods Enzymol. 34: 653-670.

7. Cuatrecasas, P. 1971. Insulin-receptor interactions in 
adipose tissue cells: direct measurement and properties. Proc. Natl. Acad. Sci. U.S.A. 68: 1264-1268.

8. Cuatrecasas, P., B. Desbuquois, and F. Krug. 1971. Insulin receptor interactions in liver cell membranes. Biochem. Biophys. Res. Commun. 44: 333-339.

9. Cuatrecasas, P. 1972. Isolation of the insulin receptor of liver and fat cell membranes. Proc. Natl. Acad. Sci. U.S.A. 69: 318-322.

10. Yokono, K., Y. Imamura, H. Sakai, and S. Baba. 1979. Insulin degrading activity of plasma membranes from rat skeletal muscle. Diabetes. 28: 810-817.

11. Harrison, L. C., T. Billington, L. J. East, R. J. Nichols, and S. Clark. 1978. The effect of solubilization on the properties of the insulin receptor of human placental membranes. Endocrinology. 102: 1485-1495.

12. Cuatrecasas, P. 1971. Properties of the insulin receptor of isolated fat cell membranes. J. Biol. Chem. 246: 72657274.

13. Pilkis, S. J., R. A. Johnson, and C. R. Park. 1972. Characterization of the insulin receptor of rat liver plasma membranes. Diabetes. 21(Suppl. 1): 335.
14. Schweitzer, J. B., R. M. Smith, and L. Jarrett. 1980. Differences in the organizational structure of the insulin receptor of rat adipocyte and liver plasma membranes: the role of disulfide bonds. Proc. Natl. Acad. Sci. U.S.A. 77: 46924696.

15. Yip, C. C., C. W. Yeung, and M. L. Moule. 1978. Photoaffinity labeling of insulin receptor of rat adiopocyte plasma membrane. J. Biol. Chem. 253: 1743-1745.

16. Yip, C. C., C. W. T. Yeung, and M. L. Moule. 1980. Photoaffinity labeling of insulin receptor proteins of liver plasma membrane preparations. Biochemistry 19: 70-76.

17. Wisher, M. H., M. D. Baron, R. H. Jones, P. H. Sonksen, D. J. Haunders, P. Thamm, and D. Brandenburg. 1980. Photoreaction of insulin analogs used to characterize the insulin receptor. Biochem. Biophys. Res. Commun. 92: 492-498.

18. Olefsky, J. M., and H. Chang. 1979. Further evidence for functional heterogeneity of adipocyte insulin receptors. Endocrinology. 104: 462-466. 